\title{
Farmers Characteristics and Efficiency Levels of Organic Rice Businesses
}

\author{
Suswadi ${ }^{*}$ and Ratih Dwi Kartikasari \\ Agribusiness Study Program, Faculty of Agriculture, Tunas Pembangunan University, \\ Jl. Balekambang No 01 Manahan, Surakarta, Central Java, Indonesia
}

\begin{abstract}
Organic agriculture as a solution to the farmers and consumers as awareness use of the synthetic chemicals in agricultural. The feasibility of farming was a requirement to ensure the sustainability of the development of organic agriculture. The purpose of this study was to determine the characteristics of farmers, the cost, revenue, and income of organic rice farming, and to analyze the efficiency of organic rice farming in Gentungan, Karanganyar Regency. Purposive random sampling and descriptive method used in this research, while the level of profit by using the return cost ratio ( $\mathrm{R} / \mathrm{C}$ ratio). Based on the results, $66 \%$ of farmers' age ranged from 41 to 60 years, primary school with $67 \%$, farming experience ranged from 5 to 10 years around $93 \%$, land ownership area of 1,000-2,000 $\mathrm{m}^{2}$ was $73 \%$. The total cost required in the organic rice farming was IDR $3,779,839$. Which consists of cash costs to IDR 2,142,506 and costs calculated as much as IDR 1,637,333. Meanwhile, the revenue was $99,900,000$ rupiah. Income on cash costs to $97,757,494$ rupiah and net income of IDR 96,120,161. The analysis of $\mathrm{R} / \mathrm{C}$ was $26.4(\mathrm{RC}>1)$ indicates that organic rice produced by farmer in Gentungan was feasible.
\end{abstract}

\section{Introduction}

Organic farming is a system of agricultural practices that utilize natural materials, such as compost, biofertilizers, and natural pesticides, as well as locally adapted plant varieties. Organic products are safe for humans, and organic farming contributes to environmental preservation. The majority of consumers will choose food that is safe for health and environmentally friendly, because organic farming is part of the latest efforts to promote a farming system that is both socially and ecologically sustainable [1]. A healthy lifestyle has become a new trend and has been institutionalized internationally which requires agricultural products to have several attributes such as safe for consumption, high nutritional content, and environmentally friendly. Organic farming is one of several approaches to meet the goals of sustainable agriculture. This is due to various comparative advantages, among others 1) there are still many land resources that can be cleared to develop organic farming systems, 2) technology to support organic farming is quite available such as composting, planting without tillage, biological pesticides, and others.

* Corresponding author: suswadi slo@yahoo.com 
According to [2] One of the centers for the development of organic agriculture in Central Java Province is Karanganyar Regency.

Rice is one of the commodities that have bright prospects to increase the income of farmers. This can motivate farmers to further develop and increase their production in the hope that at harvest time they will get high sales results to meet their needs. However, when the actual harvest arrives, the yield is abundant but the price drops, and even more so if the expected production results are far from the estimates, namely the number of buyers is very low, production is minimal, costs for production activities are high, starting from the procurement of fertilizers, processing, pesticides and other unexpected costs [3].

Gentungan Village, Mojogedang District is one of the villages in Karanganyar Regency with a population of 5740 people and 885 of them work as farmers [4]. With a large area of land and organic rice production in Mojogedang District, it turns out that there are still many problems faced by farmers, including when the harvest arrives with abundant results, their income is still very low compared to management costs and other unexpected costs. sold to local traders in Mojogedang District. Another problem is the absence of an agency that facilitates the distribution or marketing of rice production, resulting in uneven income received by farmers in the Mojogedang District.

Based on the researchers's early sighting, almost all farmers do not do business analysis on their farms, many farmers do not know how much the costs incurred during the production process so that farmers do not know the level of profit obtained. The purpose of this study was to determine the cost, revenue, and income of organic rice farming in Gentungan Village, Mojogedang District, Karanganyar Regency, and analyze the efficiency of organic rice farming in Gentungan Village, Mojogedang District, Karanganyar Regency.

\section{Method}

This research was conducted in Gentungan Village, Mojogedang District, Karanganyar Regency from January to March 2021. The population in this study were all organic rice farmers who produce in Gentungan Village, Mojogedang District, Karanganyar Regency. The sampling method in this study was done by purposive random sampling because majorty of population was farmers. The method of data collection was carried out using a survey method on 30 organic rice farmers [5]. Collecting data using a questionnaire or a structured list of questions to determine the characteristics of farmers, farm characteristics, use of rice agricultural inputs, and production. Data were collected in the form of primary data.

Data analysis was carried out descriptively with qualitative-quantitative methods. Descriptive analysis was used to describe the characteristics of farmers and the performance of organic rice farming, while quantitative analysis was used to assess income, production costs, and the feasibility of rice farming. The formula used to determine the level of efficiency of farming is the following formula:

a. Farming income [6]

Can be formulated as follows:

$$
\mathrm{I}=\mathrm{TR}-\mathrm{TC}
$$

refers to Income (IDR), TR refers to Total Revenue (IDR) and TC refers to Total Cost (IDR)

b. Farming Efficiency

Return/Cost is the ratio between total revenue and total cost :

$$
\mathrm{R} / \mathrm{C}=\frac{\text { Total Revenue }}{\text { Total cost }}
$$


$\mathrm{R} / \mathrm{C}$ refers to Return cost ratio, TR refers to Total Revenue and TC refers to Total Cost

In rice farming, TR (total revenue) is the entire income obtained from the sale of successfully harvested rice. While TC (total cost) is all costs incurred during the farming process.

Decision criteria, if $\mathrm{R} / \mathrm{C}>1$ included in the efficient criteria, $\mathrm{R} / \mathrm{C}<1$ included in the not efficient criteria, and $\mathrm{R} / \mathrm{C}=1$ included in the break even criteria.

\section{Result and Discussion}

\subsection{Characteristic of Farmer Household}

Characteristics of respondents include age, education level, experience in farming and the number of families that must be borne as well as land area.

Table 1. Socio-Economic Condition of Farmers Household in Gentungan Village, Mojogedang District, Karanganyar Regency

\begin{tabular}{|c|c|c|c|}
\hline No. & Farmer Profile & Amount & Percentage (\%) \\
\hline 1 & Age & 2 & 8 \\
& 20-30 years & 1 & 3 \\
& 31-40 years & 10 & 33 \\
& $41-50$ years & 10 & 33 \\
& $51-60$ years & 6 & 20 \\
& 61-70 years & 1 & 3 \\
\hline 2 & Ed0 years & 20 & 67 \\
& Primary School & 3 & 10 \\
& Junior High School & 4 & 13 \\
& Senior High School & 3 & 10 \\
\hline 3 & University & 2 & 7 \\
& Farming Experience & 28 & 93 \\
\hline 4 & $4-5$ years & & 73 \\
& $>5-10$ years & 22 & 20 \\
\hline & Land area & 6 & 7 \\
\hline
\end{tabular}

One of the indicators in determining work productivity in conducting business development is the age level, where the relatively young age of farmers is stronger, agile, easy to accept new innovations, responsive to the surrounding environment when compared to workers who already have a relatively old age who often refuse new innovation. The level of education will affect the way of working, the ability to make a person's decision, the speed of adoption of new innovations, farm management to marketing. The highest level of education of farmers is elementary school, which is 20 people or $67 \%$, while farmers with junior high and high school education are only 3 and 4 people or only $10 \%$ and $13 \%$. Respondent farmers in Gentungan Village are still low-educated, for this reason, agricultural extension workers are required to work hard in guiding farmers to change their mindset so that they can accept new innovations. [7] the level of education becomes a determining factor in business development and increasing productivity. People with higher 
education are relatively faster in implementing technology adoption [8]. Vice versa, those with low education are rather difficult to implement innovation adoption quickly.

The average organic rice farming experience of respondents is quite sufficient, namely 5-10 years, farming experience is capital to develop farming, farming experience plays a role in the process of farming activities. The longer a farmer does farming activities, the more experienced he will be, this happens because the farming process is a process that requires learning so that farming experience plays a role in increasing agricultural production [9].

Farmers in Gentungan Village have varied land areas, with the majority of land ownership being $1,000-2,000 \mathrm{~m}^{2}$, which is $73 \%$. [10] stated that land area has a positive or influential relationship with organic rice production. Land area greatly affects farmers in accepting and applying technology to increase production yields.

\subsection{Analysis of Organic Rice Farming}

Table 2. Total Cost of Organic Rice Management

\begin{tabular}{|c|c|c|}
\hline No. & Information & Amount (IDR) \\
\hline \multirow[t]{15}{*}{1} & Cash cost & \\
\hline & a. $\quad$ Production Facility Cost & \\
\hline & - $\quad$ Rice Seeds & 88,167 \\
\hline & - $\quad$ Manure & 286,667 \\
\hline & - $\quad$ Liquid Fertilizer & 150,973 \\
\hline & b. Labour outside family cost & \\
\hline & - $\quad$ Seed Removal & 130,667 \\
\hline & - $\quad$ Planting & 275,333 \\
\hline & Harvesting & 554,333 \\
\hline & c. Others & \\
\hline & - $\quad$ Delivery cost & 49,533 \\
\hline & - $\quad$ Plow cost & 210,000 \\
\hline & - $\quad$ Paddy Threshing cost & 230,333 \\
\hline & - $\quad$ Rice mill & 166,500 \\
\hline & Cash charge cost & $2,142,506$ \\
\hline 2 & Calculated costs & \\
\hline & a. Equipment depreciation & \\
\hline & - Hoe & 33,300 \\
\hline & - $\quad$ Sickle & 16,700 \\
\hline & - $\quad$ Sprayer & 80,000 \\
\hline & b. Labour family cost & \\
\hline & - $\quad$ Land cultivation & 248,000 \\
\hline & - $\quad$ Seed removal & 105,000 \\
\hline & - $\quad$ Planting & 218,000 \\
\hline & - $\quad$ Weeding & 160,000 \\
\hline & - $\quad$ Fertilizer & 102,000 \\
\hline & - $\quad$ Spraying & 120,000 \\
\hline & - $\quad$ Harvesting & 554,333 \\
\hline & Total cost calculated & $1,637,333$ \\
\hline & Total cost & $3,779,839$ \\
\hline
\end{tabular}

Cash costs are costs incurred by farmers directly. Cash costs consist of agricultural input costs such as fertilizers, seeds, pesticides, and labor outside the family as well as other 
costs. While the costs that are taken into account are costs that are not paid in cash but are calculated in farming. The costs taken into account include depreciation of equipment and labor costs in the family. From the table above, it can be seen that the total cost of organic rice management expenses in Gentungan Village is IDR 3,779,839,- which includes all farming costs such as agricultural production costs of IDR 525,807,-, labor outside the family of IDR 960,333,-, costs others IDR 656,366,-, depreciation of equipment isIDR. 130,000 ,- and labor costs in the family are IDR 1,507,463 -. The largest proportion of costs incurred by farmers is related to the payment of labor wages. stated that the highest expenditure on organic rice farming was in labor wages. This is because in organic farming the intensity of labor required is still very high, such as in soil processing, seed extraction, planting, and harvesting $[11,12]$.

Table 3. Average Organic Rice Farming Income

\begin{tabular}{|l|l|l|r|r|}
\hline No. & \multicolumn{1}{|c|}{ Information } & Price of rice & $\begin{array}{c}\text { Volume } \\
\text { (kg) }\end{array}$ & \multicolumn{1}{c|}{$\begin{array}{c}\text { Amount } \\
\text { (IDR) }\end{array}$} \\
\hline 1 & Farming Income & & & \\
\hline & - Total production & 10,000 & 9,900 & $99,000,000$ \\
\hline & Total income & & & $\mathbf{9 9 , 0 0 0 , 0 0 0}$ \\
\hline 2 & Farming cost & & & \\
\hline & a. Cash cost & & & \\
\hline & - Farming production cost & & & 525,807 \\
\hline & - Labour outside family cost & & & 960,333 \\
\hline & - Others & & & 656,366 \\
\hline & Total cash cost & & & $2,142,506$ \\
\hline & b. Calculated cost & & \\
\hline & $-\quad$ Equipment depreciation & & & 130,000 \\
\hline & $-\quad$ Labour family cost & & & $1,507,333$ \\
\hline & Total cost calculated & & & $1,637,333$ \\
\hline 3 & Total cost & & & $\mathbf{3 , 7 7 9 , 8 3 9}$ \\
\hline 4 & Income on cash costs & & $\mathbf{9 6 , 8 5 7 , 4 9 4}$ \\
\hline 5 & Net income (profit) & & $\mathbf{9 5 , 2 2 0 , 1 6 1}$ \\
\hline
\end{tabular}

The results of organic rice production that are managed are partly still for own consumption and partly sold to cover non-rice needs and costs for further production. Most of the farmers are aware that organic rice production will result in a higher market price compared to non-organic rice prices. Likewise with the awareness of increasing health standards by consuming organic rice. However, few farmers are aware of the other benefits of organic farming activities such as soil improvement and reduced production costs [13].

Respondent farmers usually sell their harvests in the form of rice for IDR $10,000 / \mathrm{Kg}$. To find out that organic rice farming has benefited farmers or not, it is necessary to do calculations. The calculation can be done by way of receipts minus the overall production costs. The total cost required in the respondent's organic rice farming is IDR $3,779,839,-$. Which consists of cash costs of IDR 2,142,506, - and calculated costs of IDR 1,637,333, - . While the receipt of IDR 99,000,000, -.

To find out the organic rice farmers' respondent farming in Gentungan Village earns profit, loss or break-even then Return Cost Ratio (RCR) analysis is used, namely by comparing the income during one planting period, which is IDR 99.000.000,- with production costs during one planting period. which is IDR $3,779,839$, - so that the RCR value is 26.4. The Return Cost Ratio value obtained in the organic rice farmer respondent's farm in Gentungan Village is 26.4 meaning that every IDR 1.00 cost incurred will get a 
receipt of IDR 26.4. With the RCR criteria $>1=$ efficient, then the farming of organic rice farmers in Gentungan Village is efficient.

\section{Conclusion}

Characteristics of Farmers based on age ranged from 41-60 years as much as $66 \%$, the most educated level of farmers was elementary school, namely $67 \%$, farming experience ranged from 5-10 years around $93 \%$ and land ownership area of $1,000-2,000 \mathrm{~m}^{2}$ as much as $73 \%$. The total cost required for organic rice farming by respondent farmers in Gentungan Village was IDR 3,779,839,-- The Return Cost Ratio (RCR) of organic rice farming is 26.4, from the calculation of revenue divided by the total cost. This means that for every IDR 1.00 spent, you will get an income of IDR 26.4.

\section{References}

1. S. Chouichom and M. Yamao. Journal of Organic System. 5 (1), 25-35 (2010)

2. A. Suharyati, S. Hartono, and L.R.Waluyati. Journal of Ilmu Pertanian Agricultural Sciene. 1(1), 25-30 (2017)

3. I.S. Roidah. Jurnal Agribisnis Fakultas Pertanian Unita. 11(13), 45-55 (2015)

4. Dispermadesdukcapil Provinsi Jawa Tengah, Kependudukan Desa Gentungan, Kecamatan Mojogedang, Kabupaten Karanganya, Provinsi Jawa Tengah, (2009), https://sidesa.jatengprov.go.id/desa/33.13.15.2009. Accessed date: 11 September 2021

5. Gay, LR, Geoffrey E. Mills and Peter Airasian. 2009. Educational Research, Competencies for Analysis and Application. New Jersey: Pearson Education, Inc.

6. Soekartawi. Analisis Usahatani. (UI Press. Jakarta, 2001)

7. E. Saputra, L. Fitriana, E.Bahar. Jurnal Penelitian Sungkai. 1(1), 23-31 (2012)

8. T.R. Saridewi and S.A. Nani. Jurnal Penyuluhan Pertanian. 5(1), 55-61 (2010)

9. E. Saputra, L. Fitriana, E.Bahar. Jurnal Penelitian Sungkai. 1(1), 23-31 (2012)

10. F.W. Novianto and E. Setyowati. Jurnal Ekonomi Pembangunan. 10(2), 267-288 (2009)

11. M. Nurlela, N. Kusnadi, Y. Syaukat. Forum Agribisnis. 6(2), 145-161 (2016)

12. M.P.Natriasukma, S. Hardyastuti, Irham. Journal of Agribusiness Management and Development. 2(1), 76-88 (2021)

13. R. Khoy, T. Nanseki, Y. Chomei. International Journal of Humanities and Social Science. 7(4), 92-103 (2017) 